\title{
Factors predicting prolonged hospitalization after abdominal wall hernia repair - a prospective observational study
}

\author{
H Shankar(D), Sathasivam Sureshkumar(D), Balakrishnan Gurushankari(D), Gubbi Samanna Sreenath(D), Vikram Kate(ID) \\ Department of Surgery, Jawaharlal Institute of Postgraduate Medical Education and Research, Puducherry, India
}

\begin{abstract}
Objective: The aim of this study was to identify the factors predicting prolonged hospitalization following abdominal wall hernia repair.

Material and Methods: This was a prospective observational study which included patients operated for elective and emergency abdominal wall hernias. Details of the patients including demographic profile, hernia characteristics, and perioperative factors were collected. Patients were followed up till discharge from the hospital to record the postoperative local and systemic complications. Patients who stayed for more than three days were considered as longer hospital stay. Analysis was performed to identify factors associated with the longer hospital stay.

Results: A total of 200 consecutive patients of abdominal wall hernia were included over a period of two years. Female sex ( $p<0.05)$, obesity ( $p=$ 0.022), and smoking and alcohol consumption (0.002) led to a prolonged hospital stay. Patients with incisional hernias ( $p<0.05)$, American Society of Anesthesiologists (ASA) class of two or more $(p=0.002)$, complicated hernia $(p=0.007)$, emergency surgeries $(p=0.002)$, general anesthesia $(p=0.001)$, longer duration of surgery ( $>60$ minutes, $p<0.05)$, usage of drain $(p<0.05)$, and surgical site infection $(S S I, p=0.001)$ were significantly associated with increased length of hospital stay. Whereas, age distribution, socio-economic status, co-morbidities, recurrent surgery, type of hernia repair and the level of surgeon did not affect the length of hospital stay.
\end{abstract}

Conclusion: The risk factors associated with prolonged hospital stay in patients undergoing abdominal wall hernia repair were female sex, obesity, smoking and alcoholism, incisional hernia, complicated hernias, higher ASA class, and prolonged duration of surgeries.

Keywords: Ventral hernia, hospital stay, stay length, hospitalization, hernia, ventral

Cite this article as: Shankar $\mathrm{H}$, Sureshkumar $\mathrm{S}$, Gurushankari B, Sreenath GS, Kate V. Factors predicting prolonged hospitalization after abdominal wall hernia repair - a prospective observational study. Turk J Surg 2021; 37 (2): 96102

\section{Corresponding Author}

Vikram Kate

E-mail:drvikramkate@gmail.com

Received: 13.08 .2020

Accepted: 10.02 .2021

Available Online Date: 30.06 .2021

o Copyright 2021 by Turkish Surgical Society Available online at www.turkjsurg.com

DOI: 10.47717/turkjsurg.2021.4961

\section{INTRODUCTION}

Abdominal hernia surgery is the most common elective general surgical procedure carried out which includes groin (inguinal, femoral), primary ventral (epigastric, umbilical), incisional and recurrent hernias $(1,2)$. There are several predictors for longer hospital stay in all types of hernia which raises healthcare costs. In general, inguinal, epigastric, and umbilical hernias have got a better outcome, lesser operative time, lesser postoperative complications, and shorter duration of hospital stay. Akinci et al. have reported that longer duration of surgery, strangulation, high American Society of Anesthesiologists (ASA) class, systemic and local postoperative complications are associated with longer hospital stay in patients with incisional hernia (3). In a similar study, coronary artery disease (CAD), chronic obstructive pulmonary disease (COPD), low serum albumin and use of steroids have been found to be risk factors for delayed wound healing and prolonged hospital stay especially in elderly patients (4). On the contrary, it has been reported that COPD, use of steroids, obesity, and previous infected wounds were not associated with risk of infection and duration of hospital stay in patients undergoing hernia repair surgery (5). Sartelli et al. have quoted that the many of the abdominal wall hernias are operated on emergency basis and this carries more incidence of postoperative complications, morbidity and hence prolonged hospital stay (6).

Longer hospital stay does not only increase the cost of health care system but also the loss of man days which has both personal and social impact. The knowledge 
about the factors which determine the duration of hospital stay will help in effective channeling and better management of healthcare resources (7). Individual studies on inguinal, ventral and incisional hernias have already been published (1-3). Hence, this assessment was carried out for abdominal wall hernias as a whole. There are limited studies in the literature determining the predictors of hospital stay following abdominal wall hernia repairs. Hence, this study was undertaken to determine the variables affecting prolonged hospitalization after abdominal wall hernia repairs.

\section{MATERIAL and METHODS}

\section{Study Design and Setting}

This was a prospective cohort study to determine the factors affecting prolonged hospitalization in patients undergoing abdominal wall hernia repair. The study was conducted in the department of Surgery, in a tertiary care hospital over a period of two years. Institute ethics committee approval was obtained. All provisions of the Declaration of Helsinki were followed in this study.

\section{Patient Enrollment and Follow-Up}

All consecutive adult patients posted for emergency and elective abdominal wall hernia repair with the preoperative diagnosis of inguinal hernia, primary ventral hernia (epigastric, umbilical and paraumbilical) and incisional hernias were included in the study. Patients with any additional surgical procedures carried out were excluded from the study. Informed written consent was taken from all patients included in the study. Patient demographic profile including age, sex, height, weight, body mass index (BMI) and socioeconomic status (8) were collected. Detailed history including significant past medical history, co-morbidities and habits of smoking and consuming alcohol were noted and a detailed clinical examination was carried out for all patients.

American Society of Anesthesiologists (ASA) class, type of anesthesia, operative procedure carried out, details of the operating procedures including duration of the procedure, type of surgery and the grade of surgeon were noted. Postoperatively patients were followed up till discharge from the hospital to record the post-operative local and systemic complications. The patients were discharged from the hospital when clinically fit as per department protocol. Patients who stayed for more than three days were considered as longer hospital stay (9). Analysis was performed to identify factors associated with the longer hospital stay. Analysis was done for preoperative, perioperative and postoperative factors predicting the length hospital stay in each group.

\section{Sample Size}

The sample size was calculated using OPENEPI ${ }^{\oplus}$ software. Considering length of hospital stay as the primary variable (6), the standard deviation of 0.90 and the power of the study as $90 \%$, the sample size was calculated to be 200 .

\section{Statistical Analysis}

The data obtained from the study was analyzed using SPSS 20.0 (IBM Corporation, New York, U.S.A) software. Various demographic, preoperative, perioperative and postoperative parameters recorded were summarized using mean/ median (continuous data) and proportions (binary data).

Chi square test or Fisher test was used for analyzing categorical variables. A multivariate logistic regression analysis with the final outcome (length of hospital stays) as the dependent factor was performed in order to identify independent predictors for the length of hospital stay after abdominal wall hernia repair. A p value of less than 0.05 was considered statistically significant.

\section{RESULTS}

A total of 200 consecutive patients with abdominal wall hernia as per inclusion criteria operated on elective and emergency basis were enrolled in the study. Age distribution of abdominal wall hernia patients ranged from 19 to 76 years with a mean age of $47.43+14.57$ years. Majority of the patients were males, with a male female ratio 2.7:1 (146 vs 54). Majority (67\%) of the patients were within the normal BMI category. The BMI ranged from $16.80-37.53 \mathrm{~kg} / \mathrm{m}^{2}$ with a mean BMl: $22.19 \pm 3.20$. Out of 149 patients, $74.5 \%$ belonged to socioeconomic class $4.64 \%$ of the patients had habit of either smoking or alcohol consumption or both. Length of stay was significantly longer in the female sex $(p<0.05)$, higher BMI $(p=0.022)$ and patients who had the habit of consuming alcohol and smoking (0.002). Whereas, age ( $p=$ $0.789)$ and socio-economic status $(p=0.699)$ did not affect the length of hospital stay (Table 1).

Groin hernias were the most common type (72.0\%) of abdominal wall hernia in the study population. Among the inguinal hernia right side being the common type with 39.5\% whereas left inguinal hernia was $22.5 \%$ and bilateral inguinal hernia was $9.5 \%$. About $5 \%$ of the patients had epigastric hernia, another $5 \%$ of patients had umbilical or paraumbilical hernia and $0.5 \%$ had femoral hernia. No rare type of hernia was encountered during the study period. About $13.5 \%$ of abdominal hernia patients presented with complications (irreducible, obstructed and strangulated). Recurrent hernia accounted for $0.5 \%$ of all abdominal wall hernias. About 39\% of the patients had pre-existing systemic illness. Majority of them had more than one co morbid illness including hypertension, diabetes, coronary artery disease etc. Majority of the patients belonged to ASA class 1 or class 2. Among all types of hernia, incisional hernia patients had significantly longer hospital stay ( $p-0.0001)$. Also, patients with complications ( $p=0.007)$, and patients with ASA class 2 or more $(p=0.002$ ) had significantly longer hospital stay (Table 2). Length of stay did not significantly differ between primary and recurrent hernia repair (0.083), and presence of co-morbidity $(p=0.118)$ did not contribute to the significantly longer hospital stay. 


\begin{tabular}{|c|c|c|c|c|}
\hline & $\begin{array}{c}\text { No of cases } \\
\text { N (\%) }\end{array}$ & $\begin{array}{l}\text { Short stay } \\
<3 \text { days }\end{array}$ & $\begin{array}{l}\text { Long stay } \\
>3 \text { days }\end{array}$ & $p$ \\
\hline $\begin{array}{l}\text { Sex } \\
\quad \text { Male } \\
\text { Female }\end{array}$ & $\begin{array}{c}146(73.0) \\
54(27.0)\end{array}$ & $\begin{array}{l}72(49.3) \\
11(20.4)\end{array}$ & $\begin{array}{l}74(50.7) \\
43(79.6)\end{array}$ & $0.0001^{*}$ \\
\hline $\begin{array}{l}\text { Age } \\
\begin{array}{l}18-40 \\
41-60 \\
>60\end{array}\end{array}$ & $\begin{array}{l}68(34.0) \\
67(33.5) \\
65(32.5)\end{array}$ & $\begin{array}{l}29(42.6) \\
26(38.8) \\
28(43.1)\end{array}$ & $\begin{array}{l}39(57.4) \\
41(61.2) \\
37(56.9)\end{array}$ & $0.789^{\#}$ \\
\hline $\begin{array}{l}\text { BMI } \\
\text { Under weight }(<18.55) \\
\text { Normal }(18.55-24.99) \\
\text { Over weight }(25.00-29.99) \\
\text { Obese }(\geq 30.00)\end{array}$ & $\begin{array}{c}24(12.5) \\
134(67.0) \\
38(19.0) \\
04(02.0)\end{array}$ & $\begin{array}{l}16(66.7) \\
53(39.6) \\
14(36.8) \\
00(00.0)\end{array}$ & $\begin{array}{c}08(33.3) \\
81(60.4) \\
24(63.2) \\
04(100.0)\end{array}$ & 0.022 \\
\hline $\begin{array}{l}\text { Socio-economic strata } \\
\text { Class } 1 \\
\text { Class } 2 \\
\text { Class } 3 \\
\text { Class } 4 \\
\text { Class } 5\end{array}$ & $\begin{array}{c}00(00.00) \\
00(00.00) \\
31(15.50) \\
149(74.50) \\
20(10.00)\end{array}$ & $\begin{array}{l}00(00.0) \\
00(00.0) \\
15(48.4) \\
60(40.3) \\
08(40.0)\end{array}$ & $\begin{array}{l}00(00.0) \\
00(00.0) \\
16(51.6) \\
89(59.7) \\
12(60.0)\end{array}$ & 0.699 \\
\hline $\begin{array}{l}\text { Personal habits } \\
\text { No habits } \\
\text { Smoking } \\
\text { Alcohol consumption } \\
\text { Both smoking and alcohol consumption }\end{array}$ & $\begin{array}{l}72(36.00) \\
24(12.00) \\
21(10.50) \\
83(41.50)\end{array}$ & $\begin{array}{l}20(27.8) \\
13(54.2) \\
15(71.4) \\
35(42.2)\end{array}$ & $\begin{array}{l}52(72.2) \\
11(45.8) \\
06(28.6) \\
48(57.8)\end{array}$ & 0.002 \\
\hline
\end{tabular}

Most of the hernia repairs were elective surgeries (88\%). Spinal anesthesia (67\%) and meshplasty for the repair were predominantly carried out in both elective and emergency set up. Trainees performed most of the procedures (89\%) and the duration of the surgery ranged from 30-180 minutes (75.38 \pm 29.22 minutes). the primary ventral hernia surgeries have taken less than 60 minutes and $66.7 \%$ incisional hernia surgeries have taken a range of 60-120 minutes. Drain was used for 44 (22\%) patients and all incisional hernia required drain placement which in turn led to prolonged duration of surgery. About 33 (16.5\%) patients developed SSI, among which incisional hernia had a higher tendency which was statistically insignificant and the level of surgeon did not affect the occurrence of SSI. General anesthesia $(p=0.001)$, emergency surgeries $(p=0.002)$, surgeries performed more than 60 minutes $(p<0.05)$, usage of drain $(p<0.05)$ and surgical site infection ( $p=0.001$ ) has significantly delayed the discharge of the patients after hernia repair. The type of repair ( $p=$ $0.314)$ and the level of surgeon $(p=1.000)$ did not significantly alter the length of stay (Table 3).

Multivariate logistic analysis was carried out for statistically significant parameters on univariate analysis such as gender (Females, p-0.031), BMI (Obese, p-0.002), personal habits (Both alcohol consumption \& smoking, p-0.008), type of hernia (Incisional hernia, p-0.0001), type of presentation (Irreducible, obstructed \& stran- gulated; p-0.023), ASA ( class 2, p-0.001), type of surgery (emergency, p-0.002), type of anesthesia (general anesthesia, p-0.001), drain usage (drain used, $p<0.05$ ), surgical site infection (present, $p-0.001)$ and the duration of surgery (60-120 minutes \& $>120$ minutes; p-0.005) (Table 4). On multivariate logistic analysis gender (Females, p-0.031), BMI (Obese, p-0.002), personal habits (Both alcohol consumption \& smoking, p-0.008), type of hernia (Incisional hernia, p-0.0001), type of presentation (Irreducible, obstructed \& strangulated; p-0.023), ASA ( class 2, p-0.001) and the duration of surgery (60-120 minutes \& >120 minutes; p-0.005) were independently associated with prolonged hospital stay.

\section{DISCUSSION}

In the present study, parameters such as female sex, obesity, alcohol consumption \& smoking, incisional hernia, irreducible, obstructed and strangulated hernia, higher ASA class, longer duration of surgery were independently associated with prolonged hospital stay. Abdominal wall hernia repair is the most commonly performed general surgical procedure accounting for $15-18 \%$ of all surgical procedures done with an incidence of 100 to 300 per 100000 per annum in various countries $(1,10,11)$. It has a major impact on the economy of the health care system as well as the patients. Analysis and the knowledge of various risk factors contributing to prolonged hospital stay in abdominal wall hernia repair not only reduces the financial burden on the 


\begin{tabular}{|c|c|c|c|c|}
\hline & $\begin{array}{c}\text { No of cases } \\
\mathrm{N}(\%)\end{array}$ & $\begin{array}{c}\text { Short stay } \\
<3 \text { days }\end{array}$ & $\begin{array}{l}\text { Long stay } \\
>3 \text { days }\end{array}$ & $p$ \\
\hline $\begin{array}{l}\text { Co-morbidity } \\
\text { Nil } \\
\text { Hypertension (HTN) } \\
\text { Diabetes mellitus (DM) } \\
\text { Ischaemic heart disease (IHD) } \\
\text { More than one comorbidity }\end{array}$ & $\begin{array}{c}143(71.50) \\
24(12.00) \\
06(03.00) \\
05(02.5) \\
22\end{array}$ & $\begin{array}{l}69(48.3) \\
06(25.0) \\
01(16.7) \\
01(20.0) \\
6\end{array}$ & $\begin{array}{c}74(51.7) \\
18(75.0) \\
05(83.3) \\
04(80.0) \\
16\end{array}$ & 0.118 \\
\hline $\begin{array}{l}\text { ASA Class } \\
\text { Class } 1 \\
\text { Class } 2 \\
\text { Class } 3 \\
\text { Class } 4\end{array}$ & $\begin{array}{l}145(72.50) \\
55(27.50) \\
00(00.00) \\
00(00.00)\end{array}$ & $\begin{array}{l}70(48.3) \\
13(23.6) \\
00(00.0) \\
00(00.0)\end{array}$ & $\begin{array}{l}75(51.7) \\
42(76.4) \\
00(00.0) \\
00(00.0)\end{array}$ & 0.002 \\
\hline $\begin{array}{l}\text { Type of hernia } \\
\text { Groin hernias } \\
\text { Primary ventral hernia } \\
\text { Incisional hernia }\end{array}$ & $\begin{array}{l}144(72.00) \\
20(10.00) \\
36(18.00)\end{array}$ & $\begin{array}{l}74(51.4) \\
09(45.0) \\
00(00.0)\end{array}$ & $\begin{array}{c}70(48.6) \\
11(55.0) \\
36(100.0)\end{array}$ & 0.0001 \\
\hline $\begin{array}{l}\text { Presentation } \\
\text { Reducible } \\
\text { Irreducible } \\
\text { Obstructed } \\
\text { Strangulated }\end{array}$ & $\begin{array}{l}173(86.50) \\
24(12.00) \\
02(01.00) \\
01(00.50)\end{array}$ & $\begin{array}{l}80(46.2) \\
03(12.5) \\
00(00.0) \\
00(00.0)\end{array}$ & $\begin{array}{l}93(53.8) \\
21(87.5) \\
02(100.0) \\
01(100.0)\end{array}$ & 0.007 \\
\hline $\begin{array}{l}\text { Previous surgery } \\
\text { Recurrent } \\
\text { Primary }\end{array}$ & $\begin{array}{c}09(04.50) \\
191(95.50)\end{array}$ & $\begin{array}{l}01(11.1) \\
82(42.9)\end{array}$ & $\begin{array}{c}08(88.9) \\
109(57.1)\end{array}$ & 0.083 \\
\hline
\end{tabular}

health care system but would also contribute to better post-operative outcomes in patients. This study brought out the major independent risk factors for prolonged hospital stay in patients undergoing hernia surgery.

Inguinal hernia is the most common type of all abdominal wall hernias and ventral hernias are the second most common type $(11,12)$. Similarly, in the present the study, inguinal hernia accounted for $72 \%$ of all the cases and incisional hernia was the second common type (18\%). Studies on abdominal wall hernias have found that age of the patients did not affect the hospital stay similar to the present study $(11,12)$. In the present study, it was found that majority of the patients were men $(73 \% \mathrm{v} / \mathrm{s}$ $27 \%)$. This trend may be due to males being more involved in strenuous physical work than females and hence there is greater incidence of abdominal hernias in males. It was also found that the duration of hospital stays with respect to the sex group, female sex being a strong predictor for prolonged hospital stay. The probable reason for this trend in the present study is the type of hernia, where most of the incisional hernia patients were women. Incisional hernia patients had significantly increased length of hospital stay. Obesity is a significant risk factor for prolonged hospital stay, development of surgical site infection and the recurrence of hernia (13-15). The present study also supported a similar view and found that higher BMI was asso- ciated with a prolonged hospital stay. This tendency towards a prolonged hospital stay in obese patients can be elucidated in view of associated comorbidities, greater likelihood of prolonged surgery and a higher incidence of surgical site infection.

Malnutrition, obesity, immunosuppression and diabetes mellitus have been significantly reported to prolong the length of hospital stay (16). In the present study, the distribution of abdominal wall hernia patients according to their socioeconomic class showed that all patients belonged to class 3 or above and the length of stay did not show any significant difference among the different socioeconomic strata (8). The reason could be that none of the study patients belonged to socioeconomic class $1 \& 2$ and hence the comparison was between the lower three strata among the socioeconomic class. It was found that the incidence of abdominal wall hernia is greater in lower socioeconomic classes, like other reports documented (17). This could be attributable to the fact that malnutrition and undernourishment are more prevalent in lower socioeconomic classes and they are exposed to more strenuous physical work compared to the higher socioeconomic class. Studies have shown that smoking interferes with collagen metabolism and weakens the abdominal wall soft tissue layers and hence is implicated as a causative factor for the development of hernia (18). Smoking and alcohol intake also lead to a prolonged hospital stay after 
Table 3. Comparison of anesthesia and surgical characteristics on prolonged hospitalization

\begin{tabular}{|c|c|c|c|c|}
\hline & $\begin{array}{c}\text { No of cases } \\
\text { N (\%) }\end{array}$ & $\begin{array}{c}\text { Short stay } \\
<3 \text { days }\end{array}$ & $\begin{array}{l}\text { Long stay } \\
>3 \text { days }\end{array}$ & $p$ \\
\hline $\begin{array}{l}\text { Type of surgery } \\
\text { Elective } \\
\text { Emergency }\end{array}$ & $\begin{array}{l}176(88.0) \\
24(12.0)\end{array}$ & $\begin{array}{l}80(45.5) \\
03(12.5)\end{array}$ & $\begin{array}{l}96(54.5) \\
21(87.5)\end{array}$ & 0.002 \\
\hline $\begin{array}{l}\text { Type of anesthesia } \\
\text { Spinal anesthesia } \\
\text { General anesthesia }\end{array}$ & $\begin{array}{l}134(67.00) \\
66(33.00)\end{array}$ & $\begin{array}{l}70(52.2) \\
13(19.7)\end{array}$ & $\begin{array}{l}64(47.8) \\
53(80.3)\end{array}$ & 0.001 \\
\hline $\begin{array}{l}\text { Type of repair } \\
\text { Anatomical repair } \\
\text { Meshplasty } \\
\text { Others* }\end{array}$ & $\begin{array}{l}31(15.50) \\
165(82.50) \\
04(02.0)\end{array}$ & $\begin{array}{l}11(35.5) \\
69(41.8) \\
03(75.0)\end{array}$ & $\begin{array}{l}20(64.5) \\
96(58.2) \\
01(25.0)\end{array}$ & 0.314 \\
\hline $\begin{array}{l}\text { Level of surgeon } \\
\text { Trainee } \\
\text { Consultant }\end{array}$ & $\begin{array}{l}178(89.00) \\
22(11.00)\end{array}$ & $\begin{array}{l}74(41.6) \\
09(40.1)\end{array}$ & $\begin{array}{c}104(58.4) \\
13(59.9)\end{array}$ & 1.000 \\
\hline $\begin{array}{l}\text { Duration of surgery } \\
<60 \text { minutes } \\
60-120 \text { minutes } \\
>120 \text { minutes }\end{array}$ & $\begin{array}{l}92(46.00) \\
94(47.00) \\
14(07.00)\end{array}$ & $\begin{array}{l}55(59.8) \\
28(29.8) \\
00(00.0)\end{array}$ & $\begin{array}{c}37(40.2) \\
66(70.2) \\
14(100.0)\end{array}$ & 0.0001 \\
\hline $\begin{array}{l}\text { Drain usage } \\
\text { Drain used } \\
\text { Drain not used }\end{array}$ & $\begin{array}{c}44(22.00) \\
156(78.00)\end{array}$ & $\begin{array}{c}00(00.00) \\
83(53.2)\end{array}$ & $\begin{array}{c}44(100.0) \\
73(46.8)\end{array}$ & $<0.05$ \\
\hline $\begin{array}{l}\text { Surgical site infection (SSI) } \\
\text { Surgical site infection } \\
\text { No complications }\end{array}$ & $\begin{array}{c}33(16.5) \\
167(83.5)\end{array}$ & $\begin{array}{c}00(00.00) \\
83(49.7)\end{array}$ & $\begin{array}{c}33(100.0) \\
84(50.3)\end{array}$ & 0.001 \\
\hline
\end{tabular}

Table 4. Multivariate logistic regression analysis for independent factors for prolonged hospitalization

\begin{tabular}{|c|c|c|c|}
\hline Variables & Odds ratio & Confidence interval & p \\
\hline Sex (Female) & 0.276 & $0.086-0.888$ & 0.031 \\
\hline Body mass index (BMI $\geq 30.00)$ & 1.18 & $1.066-1.347$ & 0.002 \\
\hline Smoking and alcohol consumption & 0.236 & $0.081-0.689$ & 0.008 \\
\hline Type of hernia (incisional hernia) & 5.659 & $2.300-13.923$ & 0.0001 \\
\hline Type of presentation (Irreducible, obstructed \& strangulated) & 3.101 & $1.171-8.211$ & 0.023 \\
\hline $\operatorname{ASA}^{*}(>$ class 3$)$ & 3.755 & $1.668-8.451$ & 0.001 \\
\hline Duration of surgery (60-120 minutes \& >120minutes) & 2.616 & $1.334-5.132$ & 0.005 \\
\hline
\end{tabular}

hernia repair (19). Similarly, in the present study, smoking and alcohol intake were significantly associated with a prolonged hospital stay.

Incisional hernia has been reported to be associated with a prolonged the length of hospital stay after hernia repair (3). Similarly, in the present study, incisional hernia was associated with prolonged hospital stay. This could be of the fact that incisional hernia in itself lengthens the duration of repair, and there are more complications associated with its repair. Irreducibility, obstruction and strangulation have been associated with prolonged duration of hospital stay after hernia repair (3). Similar findings were observed in the present study. This could be due to the fact that these surgeries may require bowel resection and anastomosis and general anesthesia leading to increase operative duration and post-operative complications leading to prolonged hospital stay. Elderly patients are associated with coexisting systemic diseases which leads to prolonged hospital stay (20). However, in the present study, co-morbidities were not associated with prolonged hospital stay as majority of the patients had groin hernias and most of the patients were less than 55 years of age.

Higher ASA and general or regional anesthesia have been reported to prolong the length of hospital stay similar to that of the present study $(3,20)$. Patients who underwent laparoscopic 
repair had significant shorter hospital stay $(9,21,22)$. In the present study, very few patients underwent laparoscopic hernia repair. Although, hernia surgery is more often carried out as an elective procedure, emergency hernia repair is associated with prolonged hospital stay $(3,23,24)$. Similar findings were noted in the present study. This is probably due to the presence of complicated hernia, hemodynamic instability as most of them belonged to a higher ASA class. As noted in the present study, other reports have also shown that longer duration of surgery was associated with a prolonged hospital stay (3). Increased duration of surgery predisposes for the increased incidence of complications related to surgery, tissue injury, and anesthesia. Use of drains in incisional hernia and ventral hernia repair prolongs the hospital stay $(4,25)$. In the present study, drain placement prolonged hospital stay. Drain usage directly increases the duration of surgery, predisposes to development of wound infection and hence prolongs the hospital stay. The higher the rate of infection, the longer the hospital stay after abdominal wall hernia repairs $(5,26,27)$. In the present study, development of SSI was associated with longer hospital stay and incisional hernia had a higher tendency to develop SSI compared to other types. It was found that the greater the duration of surgery, the higher the incidences of SSI. The occurrence of SSI could be associated with malnutrition as most of the study patients belonged to a lower socioeconomic class and also due to coexisting diseases.

The strength of this study was that it included all types of abdominal wall hernia. It compared both emergency and elective procedure. Parameters like ASA and type of anesthesia were included. Like any other study this also has limitations. Majority of the hernia repair were performed by open method, there were very limited laparoscopic repairs to compare. Although we tried to include all important variables which may lead to prolonged hospital stay, due to the inherent limitations of this type of study, some could have inadvertently been left out. This was single center study with its own limitation.

\section{CONCLUSION}

Risk factors associated with prolonged hospital stay in patients undergoing abdominal wall hernia repair were female sex, obesity, smoking and alcoholism, incisional hernia, complicated hernias, higher ASA class and prolonged duration of surgeries. The knowledge of these risk factors helps in identifying patients who may have prolonged hospital stay. This can aid in planning and reducing the burden on hospital resources as well as help the surgeons in providing better post-operative outcomes in patients undergoing abdominal wall hernia surgery.

Ethics Committee Approval: The approval for this study was obtained from Jawaharlar Institute of Postgraduate Medical Education and Research Ethics Committee (Decision No: IEC/ISC/2012/5228, Date: 10.12.2012).

Peer-review: Externally peer-reviewed.
Author Contributions: Concept - V.K.; Design - V.K., G.S.S.; Supervision - V.K. S.R., S.S.; Materials - N.A.; Data Collection and/or Processing - H.S.; Analysis and/or Interpratation - S.S., B.G., G.S.S.; Literature Review - S.S., G.S.S.; Writing Manuscript - All of authors; Critical Reviews - V.K., S.R., S.S.

Conflict of Interest: The authors declare that they have no conflict of interest.

Financial Disclosure: The authors declared that this study has received no financial support.

\section{REFERENCES}

1. Kingsorth A, Sanders DL. General introduction and history of hernia surgery. In: Kingsnorth, Andrew, LeBlanc, Karl A (eds.) Management of Abdominal Hernias. New York: Cham/Springer, 2013:3-30. [CrossRef]

2. DeBord JR. The historical development of prosthetics in hernia surgery. Surg Clin North Am 1998; 78(6): 973-1006. [CrossRef]

3. Akinci M, Yilmaz KB, Kulah B, Seker GE, Ugurlu C, Kulacoglu H. Association of ventral incisional hernias with comorbid diseases. Chirurgia (Bucur) 2013; 108(6): 807-11. [CrossRef]

4. Hesselink VJ, Luijendijk RW, De Wilt JH, Heide R, Jeekel J. An evaluation of risk factors in incisional hernia recurrence. Surg Gynecol Obstet 2013; 108(6): 807-11. [CrossRef]

5. Falagas ME, Kasiakou SK. Mesh-related infections after hernia repair surgery. Clin Microbiol Infect 2005; 11 (1): 3-8. [CrossRef]

6. Sartelli M, Coccolini F, Van Ramshorst GH, Campanelli G, Mandalà V, Ansaloni L, et al. WSES guidelines for emergency repair of complicated abdominal wall hernias. World J Emerg Surg 2013; 8(1): 50. [CrossRef]

7. Śmietański M, Lukasiewicz J, Bigda J, Lukianski M, Witkowski P, Sledzinski Z. Factors influencing surgeons' choice of method for hernia repair technique. Hernia 2005; 9(1): 42-5. [CrossRef]

8. Wani RT. Socioeconomic status scales-modified Kuppuswamy and Udai Pareekh's scale updated for 2019. J Fam Med Prim Care 2019. 8(6): 1846-9. [CrossRef]

9. Ielpo B, Duran H, Diaz E, Fabra I, Caruso R, Malavé L, et al. A prospective randomized study comparing laparoscopic transabdominal preperitoneal (TAPP) versus Lichtenstein repair for bilateral inguinal hernias. Am J Surg 2018; 216(1): 78-83. [CrossRef]

10. Mabula JB, Chalya PL. Surgical management of inguinal hernias at Bugando Medical Centre in northwestern Tanzania: our experiences in a resource-limited setting. BMC Res Notes 2012; 5: 585. [CrossRef]

11. Sangwan M, Sangwan V, Garg M, Mahendirutta P, Garg U. Abdominal wall hernia in a rural popular tion in India-is spectrum changing? Open J Epidemiol 2013; 3(3): 135-38. [CrossRef]

12. Rutkow IM. Demographic and socioeconomic aspects of hernia repair in the United States in 2003. Surg Clin North Am 2003; 83(5): 104551. [CrossRef]

13. Sarkhosh K. A systematic review of the association between obesity and inguinal hernias. In Society of American Gastrointestinal and Endoscopic Surgeons (SAGES) 2012 Annual Meeting 2012. [CrossRef]

14. Sauerland $S$, Korenkov M, Kleinen T, Arndt M, Paul A. Obesity is a risk factor for recurrence after incisional hernia repair. Hernia 2004; 8(1): 42-6. [CrossRef]

15. Owei L, Swendiman RA, Kelz RR, Dempsey DT, Dumon KR. Impact of body mass index on open ventral hernia repair: a retrospective review. Surgery 2017; 162(6): 1320-9. [CrossRef] 
16. Ahn BK. Risk factors for incisional hernia and parastomal hernia after colorectal surgery. J Korean Soc Coloproctol 2012: 28(6): 280-1. [CrossRef]

17. Vad MV, Frost P, Bay-Nielsen M, Svendsen SW. Impact of occupational mechanical exposures on risk of lateral and medial inguinal hernia requiring surgical repair. Occup Environ Med 2012; 69(11): 802-9. [CrossRef]

18. Misiakos E, Bagias G, Zavras N, Tzanetis P, Patapis P, Machairas A. Strangulated inguinal hernia. Inguinal Hernia 2014; 4: 87. [CrossRef]

19. Ruhl CE, Everhart JE. Risk factors for inguinal hernia among adults in the US population. Am J Epidemiol 2007; 165(10): 1154-61. [CrossRef]

20. Kulah B, Duzgun AP, Moran M, Kulacoglu IH, Ozmen MM, Coskun MF. Emergency hernia repairs in elderly patients. Am J Surg 2001; 182(5):455-9. [CrossRef]

21. Martorana G, Carlucci M, Alia C, Barrianco G, Iacopinelli SM, Labruzzo C, et al. Laparoscopic incisional hernia repair: our experience and review of the literature. Chir Ital 2007; 59(5): 671-7. [CrossRef]
22. Chowbey PK, Sharma A, Mehrotra M, Khullar R, Soni V, Baijal M. Laparoscopic repair of ventral/incisional hernias. J Minim Access Surg 2006; 2(3): 192-8. [CrossRef]

23. Primatesta P, Goldacre MJ. Inguinal hernia repair: incidence of elective and emergency surgery, readmission and mortality. Int J Epidemiol 1996; 25(4): 835-9. [CrossRef]

24. Helgstrand F, Rosenberg J, Kehlet H, Bisgaard T. Outcomes after emergency versus elective ventral hernia repair: a prospective nationwide study. World J Surg 2013; 37(10): 2273-9. [CrossRef]

25. White TJ, Santos MC, Thompson JS. Factors affecting wound complications in repair of ventral hernias. Am Surg 1998; 64(3):276-80. [CrossRef]

26. Szczerba SR, Dumanian GA. Definitive surgical treatment of infected or exposed ventral hernia mesh. Ann Surg 2003; 237(3):437-41. [CrossRef]

27. Finan KR, Vick CC, Kiefe Cl, Neumayer L, Hawn MT. Predictors of wound infection in ventral hernia repair. Am J Surg 2005; 190(5):676-81. [CrossRef]

\section{ORIJINAL ÇALIŞMA-ÖZET}

Turk J Surg 2021; 37 (2): 96-102

\section{Karın duvarı fıtığı onarımı sonrası uzamış hastanede kalmayı öngören faktörler - prospektif gözlemsel çalışma}

H Shankar, Sathasivam Sureshkumar, Balakrishnan Gurushankari, Gubbi Samanna Sreenath, Vikram Kate

Jawaharlal Lisansüstü Tıp Eğitimi ve Araştırma Enstitüsü, Cerrahi Anabilim Dalı, Puducherry, Hindistan

\section{ÖZET}

Giriş ve Amaç: Karın duvarı fıtığı onarımının ardından hastanede kalış süresinin uzamasını öngören faktörleri belirlemek.

Gereç ve Yöntem: Bu, elektif ve acil abdominal duvar fıtığı nedeniyle opere edilen hastaları içeren prospektif bir gözlemsel çalışmadır. Demografik profil, fıtık özellikleri ve perioperatif faktörler dahil olmak üzere hastaların detayları toplandı. Postoperatif lokal ve sistemik komplikasyonları kaydetmek için hastalar hastaneden taburcu oluncaya kadar takip edildi. Üç günden fazla kalan hastalar hastanede kalış süresi olarak kabul edildi. Daha uzun hastanede kalış ile ilişkili faktörleri belirlemek için analiz yapıldı.

Bulgular: İki yıllık bir süre boyunca 200 ardışık karın duvarı fıtığı hastası dahil edildi. Kadın cinsiyeti $(p<0,05)$, obezite $(p=0,022)$, sigara ve alkol tüketimi $(0,002)$ hastanede uzun süre kalmıştır. Kesi fıtığı olan hastalar $(p<0,05)$, Amerikan Anesteziyologlar Derneği (ASA) sınıfı 2 veya daha fazla $(p=0,002)$, karmaşık fitık $(p=0,007)$, acil ameliyatlar $(p=0,002)$, genel anestezi $(p=0,001))$, daha uzun cerrahi süresi $(>60$ dakika; $p<0,05)$, dren kullanımı $(p<0,05)$ ve cerrahi alan enfeksiyonu (SSI; $p=0,001)$ hastanede kalış süresinin artması ile anlamlı derecede ilişkili idi. Oysa yaş dağılımı, sosyo-ekonomik durum, eşlik eden hastalıklar, tekrarlayan cerrahi, fıtık tipi ve cerrah seviyesi hastanede kalış süresini etkilemedi.

Sonuç: Karın duvarı fıtığı tamiri yapılan hastalarda hastanede uzun süre kalmayla ilişkili risk faktörleri kadın cinsiyet, obezite, sigara ve alkolizm, insizyon fıtığı, komplike fıtıklar, daha yüksek ASA sınıfı ve uzamış ameliyat süreleridir.

Anahtar Kelimeler: Ventral herni, hastanede kalma, kalma süresi, yatış, fıtık, ventral

Doi: $10.47717 /$ turkjsurg.2021.4961 